Article

\title{
Relationship between Weather Variables and New Daily COVID-19 Cases in Dhaka, Bangladesh
}

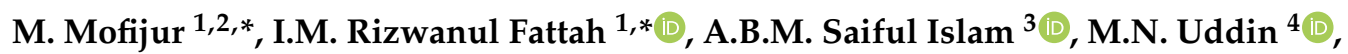 \\ S.M. Ashrafur Rahman ${ }^{5}\left({ }^{\circ}\right.$, M.A. Chowdhury ${ }^{6}{ }^{\circ}$, Md Asraful Alam ${ }^{7, *}$ and Md. Alhaz Uddin 8 \\ 1 Faculty of Engineering and Information Technology, University of Technology Sydney NSW 2007, Australia \\ 2 Mechanical Engineering Department, Prince Mohammad Bin Fahd University, \\ Al Khobar 31952, Saudi Arabia \\ 3 Department of Civil and Construction Engineering, College of Engineering, \\ Imam Abdulrahman Bin Faisal University, Dammam 31451, Saudi Arabia; asislam@iau.edu.sa \\ 4 Department of Electrical and Electronic Engineering, Northern University Bangladesh, \\ Dhaka 1213, Bangladesh; mnuddin@nub.ac.bd \\ 5 Biofuel Engine Research Facility, Queensland University of Technology (QUT), \\ Brisbane, QLD 4000, Australia; s2.rahman@qut.edu.au \\ 6 Department of Mechanical Engineering, Dhaka University of Engineering and Technology (DUET), \\ Gazipur 1707, Bangladesh; asad@duet.ac.bd \\ 7 School of Chemical Engineering, Zhengzhou University, Zhengzhou 450001, China \\ 8 Department of Civil Engineering, College of Engineering, Jouf University, Sakaka 42421, Saudi Arabia; \\ malhaz@ju.edu.sa \\ * Correspondence: MdMofijur.Rahman@uts.edu.au (M.M.); IslamMdRizwanul.Fattah@uts.edu.au (I.M.R.F.); \\ alam@zzu.edu.cn (M.A.A.)
}

Received: 2 August 2020; Accepted: 1 October 2020; Published: 9 October 2020

check for updates

\begin{abstract}
The present study investigated the relationship between the transmission of COVID-19 infections and climate indicators in Dhaka, Bangladesh, using coronavirus infections data available from the Institute of Epidemiology, Disease Control and Research (IEDCR), Bangladesh. The Spearman rank correlation test was carried out to study the association of seven climate indicators, including humidity, air quality, minimum temperature, precipitation, maximum temperature, mean temperature, and wind speed with the COVID-19 outbreak in Dhaka, Bangladesh. The study found that, among the seven indicators, only two indicators (minimum temperature and average temperature) had a significant relationship with new COVID-19 cases. The study also found that air quality index (AQI) had a strong negative correlation with cumulative cases of COVID-19 in Dhaka city. The results of this paper will give health regulators and policymakers valuable information to lessen the COVID-19 spread in Dhaka and other countries around the world.
\end{abstract}

Keywords: COVID-19; climate indicators; air quality; environment; pandemic; coronavirus

\section{Introduction}

Coronavirus is a major pathogen affecting the respiratory system of humans [1,2]. On 31 December 2019, an unspecified etiological outbreak from Wuhan, Hubei, China, was reported to the World Health Organization (WHO) [3]. The novel disease, later named COVID-19 caused by SARS-COV-2, spread quickly to other countries around the globe [4]. In light of the rising danger, WHO declared COVID-19 as an international public health emergency (PHEIC) [5]. SARS-COV-2 has already infected people in most countries around the world. As of 25 September 2020, the incidence of SARS-COV-2 infections reached the figure of more than 32 million, with more than 213 countries and regions affected by the pandemic [6]. It has been reported that in the worst-case scenario, 
COVID-19 patients can have trouble breathing and can have pneumonia, which results in death [7]. Clinical diagnosis has identified that COVID-19 patients have similar indications to other coronavirus affected patients, e.g., Middle East respiratory syndrome (MERS) and severe acute respiratory syndrome (SARS) [8]. The initial indication of SARS-COV-2 infection is cough, fever, short breath, and in the late stage, it can damage the kidneys, cause pneumonia, and unexpected death. Worldwide experience has shown that COVID-19 can affect all age groups with varying recovery rates among those groups [9]. The vulnerability of the elderly ( $>80$ years of age) is high, with a fatality rate of $\sim 22 \%$ of cases infected by COVID-19 [1].

In Bangladesh, the first coronavirus cases were identified on 8 March 2020, in three young patients (two male and one female). The two male patients had returned from Italy, and the female was a family member of one of the two males [10]. Bangladesh's infections remained low until the end of March but increased steeply in April. Bangladesh's cases reached 100 on 9 April and exceeded 200 cases in two days, so the time for the caseload to double was two days, which later slowed to three and then five days. On 1 June 2020, the time required for the caseload in Bangladesh to double remained at five days. The spread of infection was similar to that of Italy, France, and South Korea, which resulted in WHO announcing COVID-19 a pandemic [11]. Between 8 March and 1 June 2020, there were 49,534 COVID-19 cases in Bangladesh confirmed by rt-PCR, including 672 related fatalities (Case Fatality Rate 1.36\%) according to the Institute of Epidemiology Disease Control And Research (IEDCR). Figure 1 shows the COVID-19 case distribution up until 1 June 2020, in Bangladesh [12]. As of 1 June 2020, the geographical distribution of confirmed reported COVID-19 cases was available on 65\% of all cases $(32,120$ of 49,534$)$. Of these cases, $70.3 \%(22,576)$ were from Dhaka division, $16.7 \%(5361)$ Chattogram division, 3.1\% (996) Mymensingh division, 2.9\% (937) Rangpur division, 2.3\% (744) Sylhet division, 2.2\% (700) Rajshahi division, 1.8\% (574) Khulna division, and 0.7\% (232) Barisal division [13]. The highest attack rate (AR) was observed in the Dhaka division $(524.1 / 1,000,000)$, whereas Chattogram division had the second highest AR (159.5/1,000,000), and Mymensingh division had the third highest $\operatorname{AR}(76.6 / 1,000,000)$. As of 1 June 2020, according to IEDCR, a total of 320,199 COVID-19 tests, with the overall positivity rate of $15.5 \%$, were conducted in Bangladesh by 52 laboratories (28 laboratories in Dhaka and 24 laboratories in other divisions of the country).

Huang et al. [9] reported that COVID-19 was transmitted from bat to human, though the transitional host is still unidentified. The transmission of the novel virus is through air droplets from human to human. It has been reported that the temperature, humidity, wind, and precipitation may favour either the spread or the inhibition of epidemic episodes [14]. Bashir et al. [15] reported that the transmission of viruses is influenced by weather conditions and the density of people. Dalziel et al. [16] considered climate indicators as the best predictors because weather conditions play a significant role in the transmission of the coronavirus. Epstein [17] reported that the adverse weather associated with long-term changes in climate made a significant contribution to the West Nile virus spreading in the US and Europe. Even though some research has looked into identifying the link between weather variables and the spread of viruses, there is limited research on the relation between them. Most of these studies focused solely on observing the correlation of temperatures, while overlooking the impact of air quality on COVID-19 dynamics. A previous study by Haque and Rahman [18] studied the relation of temperature and humidity with COVID-19 and found that under a linear regression framework, high temperature and high humidity significantly reduced the transmission. However, they concluded that due to high local transmission, it was unlikely that the pandemic would have diminished by April. The Air Quality Index (AQI) of Bangladesh indicates that Dhaka is the most polluted city, and it is predicted that the weather variables, along with AQI at Dhaka city, are significantly correlated with the new daily COVID-19 cases. 


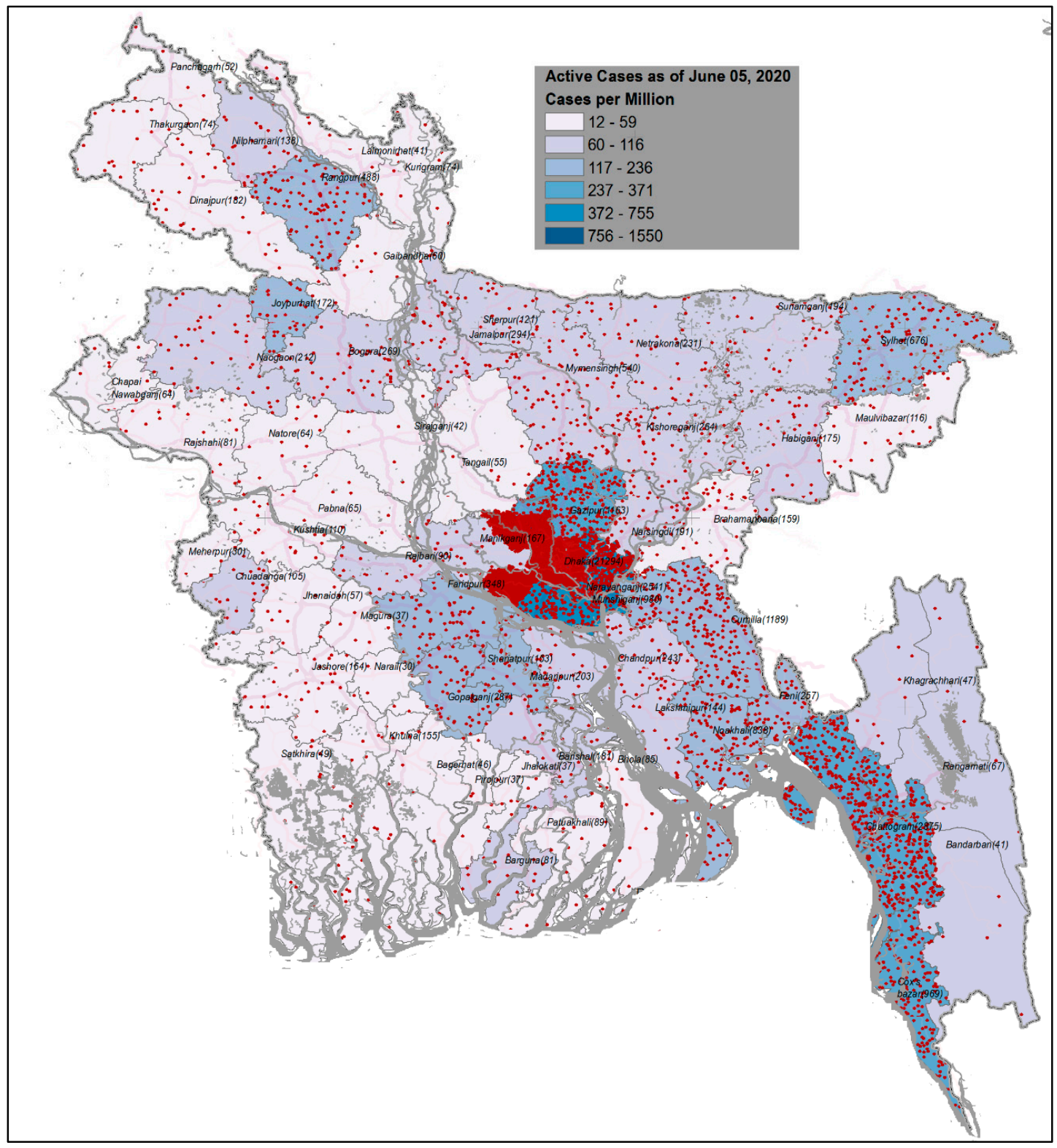

Figure 1. COVID-19 case distribution up until 1 June 2020, in Bangladesh [12].

The trajectory of an epidemic is defined by the reproduction number $\left(\mathrm{R}_{0}\right)$, which denotes the average number of secondary cases generated by one primary subject with the whole population susceptible to infection [19]. To consider a disease to be an epidemic, the value of $R_{0}$ must be greater than unity, which eventually determines the number of infected people if no intervention is placed. However, as the time elapses, control measures such as non-pharmaceutical interventions (NPIs) (and vaccines or drugs, if available) are introduced as well as the number of people susceptible to infection is exhausted, the effective reproduction number $(R)$ declines. When $R$ falls below unity in value, the epidemic starts to phase out. NPIs, including physical distancing, closure, quarantine, isolation, mask use, and hygiene behaviour, are typically aimed at reducing contact rates in the population $[20,21]$. It has been reported that the implementation of NPIs generally coincided with a rapid decline in the number of new cases [22]. Several studies have investigated the potential effect of mitigation measures on the dynamics of COVID-19 [19,21,23]. They have suggested that moderate measures could shrink the extent of the epidemic. However, extreme measures would ensure the health system is not overwhelmed, albeit at high economic and social costs [24]. This work will provide 
expedient information to the policymakers, which can help to lower the present COVID-19 infection rate through the use of NPIs and provide guidance for controlling future pandemics from the onset.

\section{Methods}

\subsection{Study Area}

Dhaka is the capital of the People's Republic of Bangladesh. Geographically, Dhaka is situated in South Asia, between $20^{\circ} 30^{\prime}$ to $26^{\circ} 38^{\prime}$ north latitude and $88^{\circ} 01^{\prime}$ to $92^{\circ} 41^{\prime}$ east longitude. It has a population of over 21 million residents. Dhaka has a tropical wet and dry climate. The city has a distinct monsoonal season, with an annual average temperature of $26^{\circ} \mathrm{C}\left(79^{\circ} \mathrm{F}\right)$, and monthly means varying between $19^{\circ} \mathrm{C}\left(66^{\circ} \mathrm{F}\right)$ in January, and $29^{\circ} \mathrm{C}\left(84^{\circ} \mathrm{F}\right)$ in May. Approximately $87 \%$ of the annual average rainfall of $2123 \mathrm{~mm}$ ( 83.6 inches) occurs between May and October. Four meteorological seasons are recognised in Dhaka as pre-monsoon (March, April, and May), monsoon (June to September), post-monsoon (October and November), and winter (December, January, and February) [25]. Dhaka is the financial, commercial, and the entertainment capital of Bangladesh. It accounts for up to $35 \%$ of Bangladesh's economy. Since its establishment as a modern capital city, the population, area, and the social and economic diversity of Dhaka have grown tremendously. Dhaka is now one of the most densely industrialised regions in the country. Dhaka is a major international city, as it hosts the headquarters of several international cooperations. By the 21st century, it emerged as a megacity, which is now listed as a beta-global city by the Globalization and World Cities Research Network (GaWC).

\subsection{Data Collection}

The computer-based data on the temporal variation of COVID-19 cases in Dhaka from the period of 1-31 May 2020, were procured from the IEDCR, Bangladesh. Until 30 April, there were a total of 6000 cases recorded (since coronavirus first identified in Bangladesh) in Dhaka and new cases increased steadily from 1 May 2020. The temporal and spatial data on climate indicators (of minimum, maximum, and average temperatures in ${ }^{\circ} \mathrm{C}$, precipitation in millimetres, and humidity as a percentage) during May 2020 were collected from the Bangladesh Meteorological Department (BMD) [15]. BMD is the only government organisation responsible for monitoring and issuing all types of forecasts and warnings related to weather events. BMD collects the daily weather data for the Dhaka city from Dhaka PBO station (international station number-41923), which is located at $23^{\circ} 46^{\prime} \mathrm{N}, 90^{\circ} 23^{\prime} \mathrm{E}$, and elevated at $8.45 \mathrm{~m}$. The AQI data was collected from Dhaka US Consulate Air Pollution: Real-time Air Quality Index [26]. The US Embassy air quality monitor measured airborne fine particulate matter on the compound of the Embassy in Dhaka.

\subsection{Data Analysis}

Data can be analysed in different ways, including using the time series modelling, Spearman, or Pearson correlation coefficient. As the objective of this study was to perform the correlational study of two temporal series of data, the Spearman rank correlation $\left(\mathrm{r}_{\mathrm{s}}\right)$ test was performed to inspect the correlation between new and total infections with environmental indicators. Spearman's correlation determines the strength and direction of the monotonic relationship between two variables. The coefficient was calculated using the following equation [16]:

$$
r_{s}=1-6 \frac{\sum d_{i}^{2}}{n\left(n^{2}-1\right)}
$$

where $d_{i}$ is the difference between the $\mathrm{x}, \mathrm{y}$ pair or the difference between the ranks of the $\mathrm{x}$ and $\mathrm{y}$ variables; $n$ is the number of coordinate pairs. 


\section{Results and Discussion}

Figure 2a shows the number of daily new infections and total infections statistics for Dhaka from 1 May 2020 to 31 May 2020. It is seen that the daily new cases were not varied steadily. For example, on 6 May, there were 540 new cases, and on 16 May, 407 cases were observed. The maximum new cases (1283) were observed on 20 May. The total confirmed cases increased steadily until the end of the month. On 1 May, the confirmed cases in Dhaka were 6031. By the end of the first week of May, confirmed cases had risen to 8289 , by the end of the second week to 11,280 , by the end of the third week to 16,528 , and by the end of the month to 22,576 .

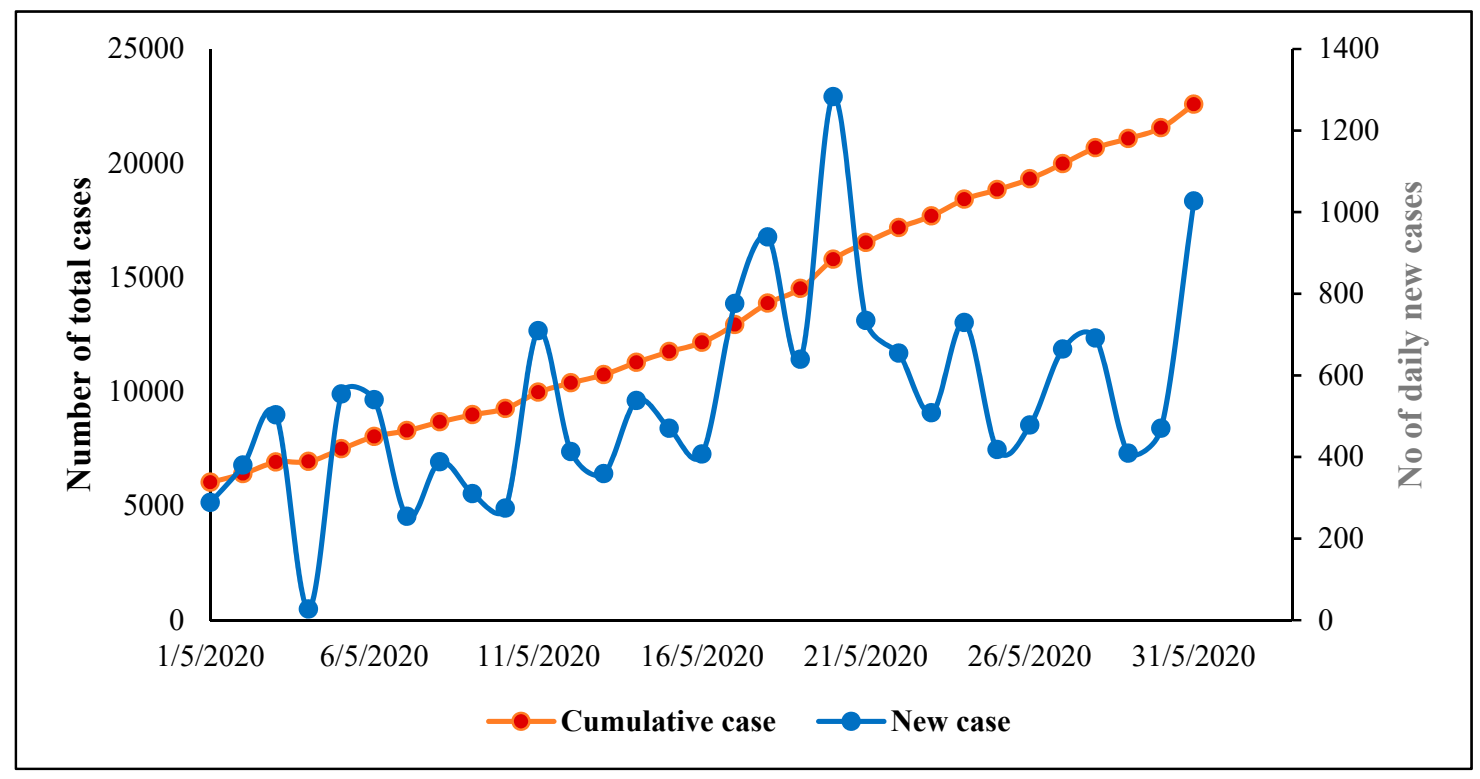

(a)

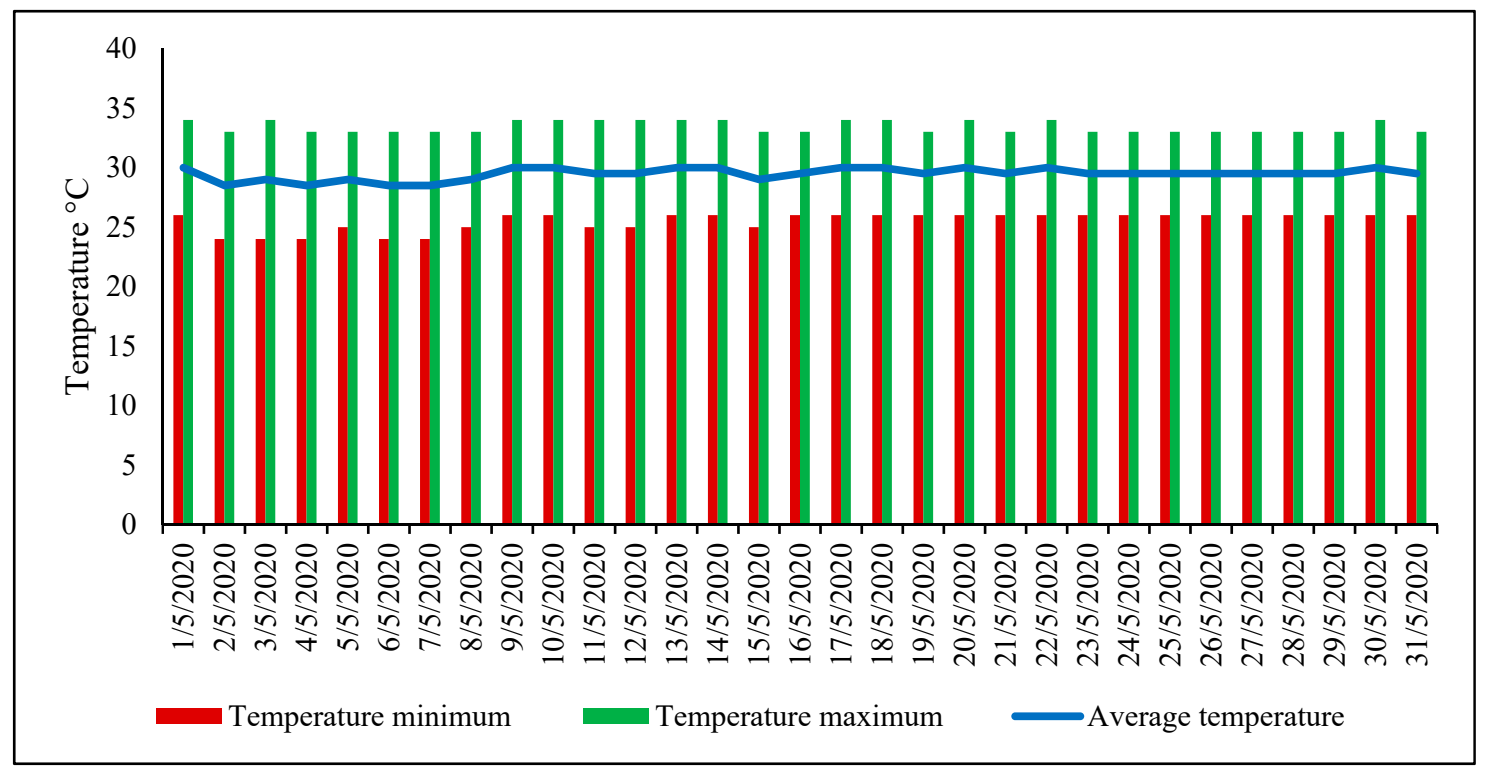

(b)

Figure 2. (a) Daily new cases and total confirmed cases of COVID-19 in Dhaka, May 2020 [4]. (b) Daily maximum, minimum, and average temperatures in Dhaka, May 2020 [14].

The daily temperature changes of Dhaka in May 2020 is depicted in Figure 2b. The lowest daily minimum, maximum, and the average temperature was $24^{\circ} \mathrm{C}, 33^{\circ} \mathrm{C}$, and $29^{\circ} \mathrm{C}$, respectively, whereas 
the highest daily minimum, maximum, and the average temperature was $26{ }^{\circ} \mathrm{C}, 34{ }^{\circ} \mathrm{C}$, and $30{ }^{\circ} \mathrm{C}$, respectively. The average daily lowest and highest rainfall was $2 \mathrm{~mm}$ and $20 \mathrm{~mm}$, respectively. The average daily minimum and maximum humidity was $47 \%$ and $98 \%$, respectively. The average daily lowest and highest wind speed was $1 \mathrm{~km} / \mathrm{h}$ and $17 \mathrm{~km} / \mathrm{h}$, respectively. The average daily minimum and maximum AQI was 54 and 150, respectively. AQI is inversely related to air quality.

Table 1 shows the correlation of these seven climate indicators with daily new infections and total infections of SARS-COV-2 in Dhaka. Among the seven weather variables, only mean temperature $\left(\mathrm{r}_{\mathrm{s}}=0.470 ; p=0.02\right)$ and minimum temperature $\left(\mathrm{r}_{\mathrm{s}}=0.427 ; p=0.01\right)$ were positively and significantly correlated with daily new infections. The mean temperature and minimum temperature indicated a significant positive relationship. The reason may be that the viral aerosols last longer in the air due to their smaller sizes at minimal or average temperature, thereby raising the spread of the virus. The AQI indicated a significant negative relationship with total confirmed infections. The reason may be that Dhaka was in full lockdown during the entire month of May so that people's mobility in and out of the region was minimal and pollutant emission was reduced due to absence of public transportation. Maximum temperature, wind speed, rainfall, and humidity were not significantly correlated with the dynamics of coronavirus.

Table 1. Relationship coefficients result between climate indicators and COVID-19 outbreak.

\begin{tabular}{cccc}
\hline & Climate Variable & New Case & Cumulative Case \\
\hline & Min. temp. & $0.427^{* * *}$ & $0.732^{* * *}$ \\
& Max. temp. & 0.156 & -0.041 \\
& Avg. temp. & $0.472^{* * *}$ & $0.701^{* * *}$ \\
Spearman correlation & Rainfall & 0.233 & 0.591 \\
Coefficient $\left(\mathrm{r}_{\mathrm{s}}\right)$ & Humidity & 0.111 & 0.013 \\
& Wind & 0.287 & 0.388 \\
& AQI & -0.205 & $-0.607^{* * *}$ \\
\hline
\end{tabular}

*** $1 \%$ significance level (two-tailed); ${ }^{* *} 5 \%$ significance level (two-tailed).

For the present study, the link between climate indicators and the spread of COVID-19 in Dhaka is analysed. Figure 3 shows the most correlation factors on daily new infections and the total number of infections. The analysis determined that the minimum and average temperatures in Dhaka were linked to the spread of COVID-19. Increasing the average temperature by $4{ }^{\circ} \mathrm{C}$ gradually lowered the COVID-19 spread. This relationship is supported by the work [27] on the respiratory syncytial virus (RSV) and [28] on SARS viruses. Previous research on the effect of climate indicators on COVID-19 dynamics indicated that temperature served as the key driver for the spread of the coronavirus in China [29], Indonesia [30], and the US [15]. Chen et al. [31] also highlighted that temperature influences the spread of the coronavirus. There are reports of other meteorological indicators affecting the dynamics of the novel coronavirus. It has been reported that humidity and temperature are crucial indicators, which significantly motivate the seasonal transmission of SARS-COV-2 [32]. However, weather parameters affect not only the transmission of the novel virus but also mortality [33]. Poole [34] cited that environment latitude also correlates with the COVID-19 pandemic. Liu et al. [35] also reported that that local weather conditions of lowered temperature, mild diurnal temperature range, and low humidity might favour the transmission.

The findings of this study have been compared with a recent study [30] undertaken in Indonesia which indicated that only mean temperature significantly affected daily cases, with other variables bearing no relationship with the COVID-19 pandemic. In this study, we also found that the average temperature was linked with daily new cases in Bangladesh $\left(r_{\mathrm{s}}=0.472\right)$ and that the observed relationship was higher than that found for Indonesia $\left(r_{s}=0.393\right)$. Unlike the Indonesian study [30], this study also considered the effect of AQI on the impact of the outbreak. We found that AQI was strongly related $\left(\mathrm{r}_{\mathrm{s}}=0.607 ; p=0.001\right)$ to total cases in Bangladesh. 


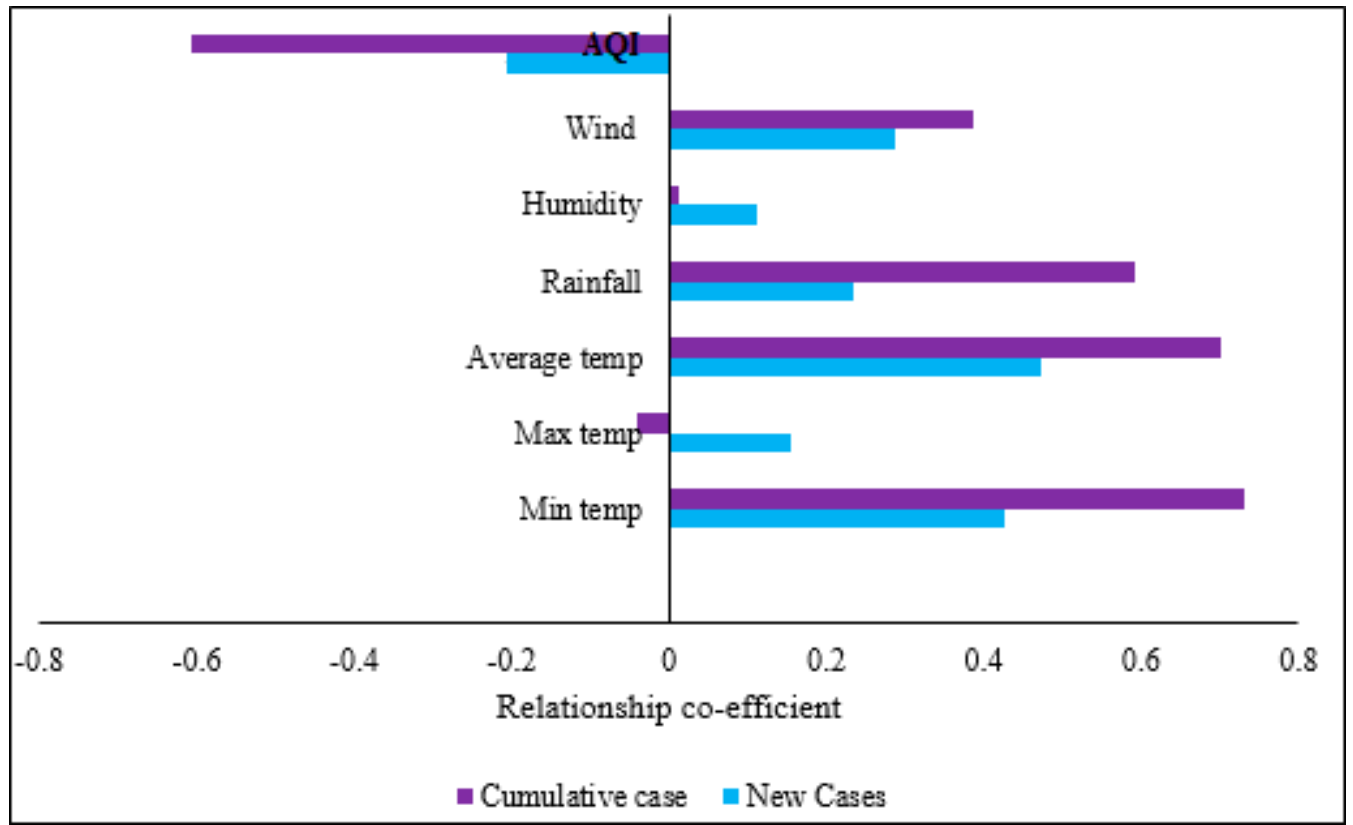

Figure 3. The comparison of $r_{\mathrm{s}}$ among the most indicators.

In Dhaka, the fast spread of COVID-19 was due to the extremely high level of human mobility, along with the weather. Being the capital city, Dhaka is the centre of almost all commercial, economic, and cultural activities of Bangladesh. Many people from regional areas in Bangladesh travel to Dhaka to find a job and develop their financial stability. Another explanation perhaps is that Dhaka has a high population density, allowing very quick transmission of SARS-COV-2. Dhaka has a population of 21 million, growing at $3.6 \%$ per year and a density of 121,720 residents per square mile, according to census data. Most of the people are involved either in households or unauthorised work and considerable proportion work in the garment industry (approximately 800,000). Such statistics make Dhaka a perfect epicentre for infection compared to other areas of the country. $\mathrm{Zu}$ et al. [36] also reported that population density is one of the causes for the rapid transmission of SARS-COV-2.

In general, the length of the incubation period (duration between exposure to the virus and the onset of symptoms) and the infectiousness period determine the initial spread, infection rate, and the probable duration of an epidemic [19]. Fast detection and isolation of infected cases, as well as social distancing, had shown to produce a more significant restrictive effect on the outbreak by other studies [24]. Davis et al. [37] assessed the influence of several control measures for mitigating the impact of COVID-19 in the UK through modelling and reported that extreme measures were required to bring the epidemic under control due to characteristics of SARS-COV-2. In addition, targeted and robust NPI measures can significantly reduce transmission to the local community, as shown by China [24].

\section{Conclusions}

Climate indicators play an essential role in determining the COVID-19 outbreak in Dhaka. This study showed a significant correlation between mean temperature, low temperature, and AQI and rapid transmission of COVID-19 infections. The outcomes of this research will provide useful information to lower the incidence rate. In particular, the significant relationship between AQI and the spread of COVID-19 infections indicated the importance of implementing clean environment policies within the country. However, further research on daily pollutant emissions, such as carbon, particulate matter, and nitrogen oxides is necessary as forced confinement due to the pandemic significantly lowered pollutant emissions. 
Despite important findings on the impact of weather on the COVID-19 pandemic, some limitations remain. For example, the infection of the novel coronavirus is influenced by many variables, including people's mobility, immunity, hygiene and proximity, the size of gatherings, testing facilities, and health care management. Therefore, further and comprehensive research is necessary to explore data about these variables to give a clearer picture of the dynamics of COVID-19.

Author Contributions: Conceptualisation, M.M. and I.M.R.F.; data curation, M.M. and A.B.M.S.I.; formal analysis, S.M.A.R. and M.A.A.; supervision, M.A.C.; writing-original draft, M.M. and I.M.R.F.; writing-review and editing, M.N.U. and M.A.U. All authors have read and agreed to the published version of the manuscript.

Funding: This research has not been externally funded.

Acknowledgments: Authors would like to acknowledge the 'research development fund' of the School of Information, Systems and Modelling, University of Technology Sydney, Australia.

Conflicts of Interest: The authors declare no conflict of interest.

\section{References}

1. Abdullah, S.; Mansor, A.A.; Napi, N.N.L.M.; Mansor, W.N.W.; Ahmed, A.N.; Ismail, M.; Ramly, Z.T.A. Air quality status during 2020 Malaysia Movement Control Order (MCO) due to 2019 novel coronavirus (2019-nCoV) pandemic. Sci. Total Environ. 2020, 729, 139022. [CrossRef] [PubMed]

2. Kabir, M.T.; Uddin, M.S.; Hossain, M.F.; Abdulhakim, J.A.; Alam, M.A.; Ashraf, G.M.; Bungau, S.G.; Bin-Jumah, M.N.; Abdel-Daim, M.M.; Aleya, L. nCOVID-19 Pandemic: From Molecular Pathogenesis to Potential Investigational Therapeutics. Front Cell Dev. Biol. 2020, 8, 616. [CrossRef] [PubMed]

3. Li, Q.; Guan, X.; Wu, P.; Wang, X.; Zhou, L.; Tong, Y.; Ren, R.; Leung, K.S.M.; Lau, E.H.Y.; Wong, J.Y.; et al. Early transmission dynamics in Wuhan, China, of novel coronavirus-infected pneumonia. N. Engl. J. Med. 2020, 382, 1199-1207. [CrossRef] [PubMed]

4. Forster, P.M.; Forster, H.I.; Evans, M.J.; Gidden, M.J.; Jones, C.D.; Keller, C.A.; Lamboll, R.D.; Quéré, C.L.; Rogelj, J.; Rosen, D.; et al. Current and future global climate impacts resulting from COVID-19. Nat. Clim. Chang. 2020. [CrossRef]

5. Sohrabi, C.; Alsafi, Z.; O’Neill, N.; Khan, M.; Kerwan, A.; Al-Jabir, A.; Iosifidis, C.; Agha, R. World Health Organization declares global emergency: A review of the 2019 novel coronavirus (COVID-19). Int. J. Surg. 2020, 76, 71-76. [CrossRef]

6. Rizwanul Fattah, I.M.; Ong, H.C.; Mahlia, T.M.I.; Mofijur, M.; Silitonga, A.S.; Rahman, S.M.A.; Ahmad, A. State of the Art of Catalysts for Biodiesel Production. Front. Energy Res. 2020, 8. [CrossRef]

7. Holshue, M.L.; DeBolt, C.; Lindquist, S.; Lofy, K.H.; Wiesman, J.; Bruce, H.; Spitters, C.; Ericson, K.; Wilkerson, S.; Tural, A.; et al. First case of 2019 novel coronavirus in the United States. N. Engl. J. Med. 2020, 382, 929-936. [CrossRef]

8. Wang, Y.; Wang, Y.; Chen, Y.; Qin, Q. Unique epidemiological and clinical features of the emerging 2019 novel coronavirus pneumonia (COVID-19) implicate special control measures. J. Med Virol. 2020, 92, 568-576. [CrossRef]

9. Masrur, A.; Yu, M.; Luo, W.; Dewan, A. Space-Time Patterns, Change, and Propagation of COVID-19 Risk Relative to the Intervention Scenarios in Bangladesh. Int. J. Environ. Res. Public Health 2020, 17, 5911. [CrossRef]

10. Paul, R. Bangladesh Confirms its First Three Cases of Coronavirus. Available online: https://www.reuters. com/article/us-health-coronavirus-bangladesh-idUSKBN20V0FS (accessed on 30 September 2020).

11. Cucinotta, D.; Vanelli, M. WHO declares COVID-19 a pandemic. Acta Biomed. 2020, 91, 157-160. [CrossRef]

12. Bengal Institute. COVID-19 in Bangladesh: Case Rates. Available online: https://bengal.institute/research/ covid19bangladesh/ (accessed on 29 September 2020).

13. World Health Organization (WHO). Bangladesh COVID-19 Situation Report No \#14, 1 June 2020. Available online: https://www.who.int/docs/default-source/searo/bangladesh/covid-19-who-bangladeshsituation-reports/who-ban-covid-19-sitrep-14-20200601.pdf? (accessed on 30 September 2020).

14. Cheval, S.; Mihai Adamescu, C.; Georgiadis, T.; Herrnegger, M.; Piticar, A.; Legates, D.R. Observed and Potential Impacts of the COVID-19 Pandemic on the Environment. Int. J. Environ. Res. Public Health 2020, 17, 4140 . 
15. Bashir, M.F.; Ma, B.; Bilal; Komal, B.; Bashir, M.A.; Tan, D.; Bashir, M. Correlation between climate indicators and COVID-19 pandemic in New York, USA. Sci. Total Environ. 2020, 728, 138835. [CrossRef] [PubMed]

16. Dalziel, B.D.; Kissler, S.; Gog, J.R.; Viboud, C.; Bjørnstad, O.N.; Metcalf, C.J.E.; Grenfell, B.T. Urbanisation and humidity shape the intensity of influenza epidemics in US cities. Science 2018, 362, 75-79. [CrossRef] [PubMed]

17. Epstein, P.R. West Nile virus and the climate. J. Urban Health 2001, 78, 367-371. [CrossRef] [PubMed]

18. Haque, S.E.; Rahman, M. Association between temperature, humidity, and COVID-19 outbreaks in Bangladesh. Env. Sci. Policy 2020, 114, 253-255. [CrossRef]

19. Anderson, R.M.; Heesterbeek, H.; Klinkenberg, D.; Hollingsworth, T.D. How will country-based mitigation measures influence the course of the COVID-19 epidemic? Lancet 2020, 395, 931-934. [CrossRef]

20. Seale, H.; Dyer, C.E.F.; Abdi, I.; Rahman, K.M.; Sun, Y.; Qureshi, M.O.; Dowell-Day, A.; Sward, J.; Islam, M.S. Improving the impact of non-pharmaceutical interventions during COVID-19: Examining the factors that influence engagement and the impact on individuals. Bmc Infect. Dis. 2020, 20, 607. [CrossRef]

21. Prem, K.; Liu, Y.; Russell, T.W.; Kucharski, A.J.; Eggo, R.M.; Davies, N.; Flasche, S.; Clifford, S.; Pearson, C.A.B.; Munday, J.D.; et al. The effect of control strategies to reduce social mixing on outcomes of the COVID-19 epidemic in Wuhan, China: A modelling study. Lancet Public Health 2020, 5, e261-e270. [CrossRef]

22. Flaxman, S.; Mishra, S.; Gandy, A.; Unwin, H.J.T.; Mellan, T.A.; Coupland, H.; Whittaker, C.; Zhu, H.; Berah, T.; Eaton, J.W.; et al. Estimating the effects of non-pharmaceutical interventions on COVID-19 in Europe. Nature. [CrossRef]

23. Kissler, S.M.; Tedijanto, C.; Goldstein, E.; Grad, Y.H.; Lipsitch, M. Projecting the transmission dynamics of SARS-CoV-2 through the postpandemic period. Science 2020, 368, 860-868. [CrossRef]

24. Lai, S.; Ruktanonchai, N.W.; Zhou, L.; Prosper, O.; Luo, W.; Floyd, J.R.; Wesolowski, A.; Santillana, M.; Zhang, C.; Du, X.; et al. Effect of non-pharmaceutical interventions to contain COVID-19 in China. Nature 2020, 585, 410-413. [CrossRef]

25. Bangladesh Meteorological Department (BMD). Meteorological seasons in Dhaka. Available online: http: //live.bmd.gov.bd/ (accessed on 29 September 2020).

26. Dhaka US Consulate Air Pollution: Real-time Air Quality Index. Available online: http://aqicn.org/city/ bangladesh/dhaka/us-consulate/ (accessed on 4 July 2020).

27. Vandini, S.; Corvaglia, L.; Alessandroni, R.; Aquilano, G.; Marsico, C.; Spinelli, M.; Lanari, M.; Faldella, G. Respiratory syncytial virus infection in infants and correlation with meteorological factors and air pollutants. Ital. J. Pediatr. 2013, 39, 1. [CrossRef] [PubMed]

28. Tan, J.; Mu, L.; Huang, J.; Yu, S.; Chen, B.; Yin, J. An initial investigation of the association between the SARS outbreak and weather: With the view of the environmental temperature and its variation. J. Epidemiol. Community Health 2005, 59, 186-192. [CrossRef] [PubMed]

29. Shi, P.; Dong, Y.; Yan, H.; Li, X.; Zhao, C.; Liu, W.; He, M.; Tang, S.; Xi, S. The impact of temperature and absolute humidity on the coronavirus disease 2019 (COVID-19) outbreak-evidence from China. medRxiv 2020. [CrossRef]

30. Tosepu, R.; Gunawan, J.; Effendy, D.S.; Ahmad, L.O.A.I.; Lestari, H.; Bahar, H.; Asfian, P. Correlation between weather and Covid-19 pandemic in Jakarta, Indonesia. Sci. Total Environ. 2020, 725, 138436. [CrossRef]

31. Chen, B.; Liang, H.; Yuan, X.; Hu, Y.; Xu, M.; Zhao, Y.; Zhang, B.; Tian, F.; Zhu, X. Roles of meteorological conditions in COVID-19 transmission on a worldwide scale. medRxiv 2020. [CrossRef]

32. Sajadi, M.M.; Habibzadeh, P.; Vintzileos, A.; Shokouhi, S.; Miralles-Wilhelm, F.; Amoroso, A. Temperature, Humidity and Latitude Analysis to Predict Potential Spread and Seasonality for COVID-19 (5 March 2020). SSRN 2020. Available online: https://ssrn.com/abstract $=3550308$ (accessed on 4 July 2020). [CrossRef]

33. Ma, Y.; Zhao, Y.; Liu, J.; He, X.; Wang, B.; Fu, S.; Yan, J.; Niu, J.; Zhou, J.; Luo, B. Effects of temperature variation and humidity on the death of COVID-19 in Wuhan, China. Sci. Total Environ. 2020, 724, 138226. [CrossRef]

34. Poole, L. Seasonal influences on the spread of SARS-CoV-2 (COVID-19), causality, and Forecastabililty (3-15-2020). SSRN 2020. [CrossRef]

35. Liu, J.; Zhou, J.; Yao, J.; Zhang, X.; Li, L.; Xu, X.; He, X.; Wang, B.; Fu, S.; Niu, T.; et al. Impact of meteorological factors on the COVID-19 transmission: A multi-city study in China. Sci. Total Environ. 2020, 726, 138513. [CrossRef] 
36. Zu, Z.Y.; Jiang, M.D.; Xu, P.P.; Chen, W.; Ni, Q.Q.; Lu, G.M.; Zhang, L.J. Coronavirus Disease 2019 (COVID-19): A Perspective from China. Radiology 2020, 200490. [CrossRef]

37. Davies, N.G.; Kucharski, A.J.; Eggo, R.M.; Gimma, A.; Edmunds, W.J.; Jombart, T.; O’Reilly, K.; Endo, A.; Hellewell, J.; Nightingale, E.S.; et al. Effects of non-pharmaceutical interventions on COVID-19 cases, deaths, and demand for hospital services in the UK: A modelling study. Lancet Public Health 2020, 5, e375-e385. [CrossRef] 